\title{
MILLION-DOLLAR MOUNTAINS: PRICES, SANCTIONS, AND THE LEGAL REGULATION OF COLLECTIVE SOCIAL AND ENVIRONMENTAL GOODS
}

\author{
JASON SCOTT JOHNSTON†
}

\section{INTRODUCTION}

Imagine a world where every aspect of the natural environment is up for cash sale or lease. Imagine that every lake and river, every environmental good, even those held in collective ownership, is freely exchangeable for money. Suppose also that in this world, any human relationship may be created, or ended, if enough money is paid. Friendships and marriages are bought and sold, like so many commodities, using the common medium of exchange, money. Would we think it odd in such a world to express our valuation of every relationship, both among human beings and between human beings and the nonhuman environment, in terms of dollars? Would we not, in such a world, speak of our million-dollar mountain, our six-figure friend?

I believe that in this still-hypothetical world, we would indeed use dollars to value all our relationships. Further, it is only because our current social and legal practices disapprove and even sanction attempts to exchange money for some relationships that we would find it unusual and objectionable to speak in such terms. We refuse to value some goods in dollar terms because the "goods" are relationships, much of the value of which would be lost were we to allow the free exchange of such relationships for money. It is not that we compartmentalize ourselves into family member versus consumer, consumer versus worker, worker versus citizen, able to rank and compare alternative jobs but completely unable to say whether a higher income is worth less than time with one's children. It is not that our diverse values are incommensurable. It is, instead, that we do not think that money is the appropriate medium in which to express these values. The task is to explain why this should be so in

† Professor of Law, University of Pennsylvania Law School. I am grateful to Dan Farber, Peter Huang, Lewis Kornhauser, and especially Eric Posner for helpful comments on an earlier version of this Article. 
order to understand the choice among alternative legal approaches to regulating and preserving collective social and environmental goods.

In this Article, I take some preliminary steps in such a direction by developing a functional, economic account of how money-price allocation of certain kinds of relationships is likely to result in the eventual destruction of the value inherent in those relationships. This account is developed first by thinking through what might be lost were relationships among human beings, such as friendship and marriage, to be freely exchangeable for money. Crucially, a restriction on money exchange is not equivalent to a restriction on all exchanges. Rather, restricting money exchange forces delayed, bartered exchange. For barter to occur, the parties must possess attributes that they value without regard to the value these goods might bring in some other relationship. The delayed, bartered reciprocity that characterizes our closest personal relationships is how we learn to trust and to cooperate. Learning to trust and cooperate is both costly, and, if effective, vulnerable to exploitation. Legal and social sanctions against attempts to contract out of reciprocity by arranging money exchanges for the services that are typically exchanged in such relationships are justified on efficiency grounds. Such sanctions reduce outside opportunities which both lessen the incentive to learn how to cooperate and increase the incentive to exploit cooperative behavior.

This functional explanation of exchange-restricted human relationships may be extended to provide a new economic perspective on the legal regulation of our interaction with the nonhuman environment. The "tragedy of the commons" - the tendency for free, collective environmental goods to be degraded by pollution and overusearises only when a collective environmental resource is provided as a free good. Economists have complained for decades that the environmental problem is simple, that all we need to do to cure the pollution problem is to attach appropriate prices, and that the failure to do so is simply a political failure caused by the enormous redistributive effects that such pricing would have. That such redistributive effects are an important explanation of actual legislative and regulatory practice in the United States is clear. The practice, however, has not been to treat collective environmental goods as free, but rather to regulate directly how such goods are used and to sanction impermissible uses. Under my approach, the question is why we use sanctions

\footnotetext{
${ }^{1}$ Garrett Hardin, The Tragedy of the Commons, 162 SCIENCE 1243, 1244 (1968).
} 
rather than prices in regulating such goods. ${ }^{2}$ The answer, I believe, is that the regime of sanctions is justified precisely by the need to overcome the collective-action problem by creating an incentive for both individual monitoring of use by others, and individual sensitivity to the effect of one's use on others. We regulate use not because we are certain of the collective impact of alternative types and levels of individual interaction with the environment, but rather because we are not. Because of that same uncertainty, we prefer sanctions to pricing due to our certainty that a use should not be permitted only if it is a gross departure from, or completely unlike, those uses that experience has indicated are generally protective of the environment. We use sanctions because environmental regulation is intended to preserve the diversity, variability, and duration, not of the natural environment, but of human relationships with it. We use sanctions, finally, because we do not want to create incentives for our collective agents to derive revenues from increases in the level of harmful activities, but to detect levels and uses that threaten too much harm.

\section{ARE VALUES INCOMMENSURABLE, OR IS MONEY THE PROBLEM?}

In the legal and philosophical literature, incommensurability has been understood to refer to at least three notions. The first, what Ruth Chang calls incomparability, is the idea that certain goods cannot be compared or ordinally ranked. ${ }^{3}$ The second, related sense is the idea that all goods cannot be valued according to a single common metric. ${ }^{4}$ This second sense is equivalent to saying that we cannot come up with a cardinal utility scale along which all goods may be ranked. The third and final sense, emphasized by Margaret Radin, is

2 The prices-versus-sanctions framework was set out first in Robert Cooter, Prices and Sanctions, 84 COLUM. L. REV. 1523, 1523-24 (1984). See also Thomas C. Schelling, Prices as Regulatory Instruments, in INCENTIVES FOR ENVIRONMENTAL PROTECTION 1, 6-7 (Thomas C. Schelling ed., 1985) (explaining that, while no moral prejudice attaches to the action for which a fee is paid, payment of a fine or sanction does not erase the offense).

s See Ruth Chang, Introduction, in INCOMMENSURABILITY, INCOMPARABILITY, AND PRACTICAL REASON 1, 1 (Ruth Chang ed., 1997). For an illustrative discussion and application of incomparability, see ELIZABETH ANDERSON, VALUE IN ETHICS AND ECONOMICS 55-59 (1993).

1 This is the sense of incommensurability employed in Cass R. Sunstein, Incommensurability and Valuation in Law, 92 MiCH. L. REV. 779, 780 (1994). 
that we either cannot or should not compare some actions or choices in terms of money prices or returns. ${ }^{5}$

As I have put them, the first two related meanings of incommensurability are badly incomplete. I have not specified what it means to say that we "cannot" rank all goods along a common ordinal or cardinal scale. One possibility is that by saying we cannot come up with such a ranking, one means that it is conceptually or logically impossible to do so. As a logical matter, it makes no sense to ask whether a particular complex number is larger or smaller than an arbitrary real number, because the very definition of real and complex numbers makes such a comparison meaningless: Complex numbers are not defined on the real line. So too, one might argue, it would make no sense to ask whether being a loving parent is better or worse than having an additional ten million dollars. Our conception of what it means to be a loving parent does not allow us to compare this good with a certain amount of money.

But just as there are many number systems, so too are there many alternative conceptions of both money and human relationships. At bottom, any assertion that it is conceptually or logically impossible to rank ordinally or cardinally alternative goods is an assertion that, as constructed by us, the goods cannot be ranked meaningfully. Thus, as Cass Sunstein explicitly has noted, incommensurability (in either the ordinal or cardinal sense) is an assertion about "widespread current attitudes" ${ }^{\prime 6}$ regarding how we value things: that reducing values to a single, unitary metric is "inconsistent with prevailing convictions" and contemporary experience. ${ }^{7}$ This makes incommensurability a behavioral claim, but like any behavioral claim, incommensurability is, of course, fully amenable to philosophical exploration. One might argue that our conception of value implies that all items of potential value are subject to some sort of order relationship (even if partial). This would amount to a conceptual refutation of incommensurability.

Although the literature on incommensurability may be unclear in the abstract about what is meant by the term, it provides plenty of concrete examples. ${ }^{8}$ These examples reveal incommensurability to be

5 See MARGaret JANE RADIN, CONTESTEd COMMODITIES 118-22 (1996); see also Kenneth J. Arrow, Invaluable Goods, 35 J. ECON. LITERATURE 757, 758-59 (1997) (analyzing Radin's arguments).

${ }^{6}$ Sunstein, supra note 4, at 790.

${ }^{7}$ Id. at 798.

${ }^{8}$ For examples of what is meant by the term "incommensurability," see Sunstein, supra note 4, at 782-85, discussed infra text accompanying notes 9-10, and Richard A. 
a hypothesis about the undesirability of exchanging certain sorts of relationships, or aspects thereof, for money.

This is true of both critics and defenders of incommensurability. For instance, to demonstrate the plurality of incommensurable values and diverse valuation, Sunstein (who may be given due credit for getting the legal incommensurability ball rolling) adduces the following examples: If one offers to pay a neighbor or friend cash to mow one's lawn or to compensate the friend for forgiving one's cancellation of lunch, then the neighbor or friend will be insulted, regardless of how much one offers; ${ }^{9}$ our sense of awe and wonder upon viewing a mountain cannot be expressed by saying that the mountain is worth a certain (large) amount of money; finally, one would be a "strange creature" if one actually thought about dating and romance as participating in a marriage market. ${ }^{10}$ In his penetrating critique of incommensurability and defense of the utility metric as an explanatory tool, Richard Epstein discusses an example put forward by Joseph Raz. In the example, a husband takes a job paying an extra $\$ 100,000$ but requiring that he live in a distant city, apart from his spouse. As characterized by Epstein, Raz argues that if the husband takes the job, then this does not imply that the husband believes an additional $\$ 100,000$ somehow can be judged more valuable than living with his spouse." According to Raz, the value of an extra $\$ 100,000$ is incommensurable with the value of living with one's spouse. Epstein finds that this ignores the likely interdependence between the husband's and the wife's utility functions, a formalization, if you will, of our notion of what it means to love another person. ${ }^{12}$ Epstein finds it "inconceivable" that the husband would make the decision to take the distant job without consulting his wife, and without sharing the additional $\$ 100,000$ with her. ${ }^{13}$ On this view, the question of whether the husband's decision to take the job indicates that he values $\$ 100,000$

Epstein, Are Values Incommensurable, or Is Utility the Ruler of the World?, 1995 UTAH L. REV. 683, 691-94 (discussing a parent's choice to work late and miss her child's band concert, to work overseas for an increased salary or professional advancement, or to take an out-of-town job that requires separation from her family).

${ }^{9}$ See Sunstein, supra note 4 , at 785-86.

${ }^{10} I d$. at 816.

${ }^{11}$ See Epstein, supra note 8, at 693-94 (discussing Raz's example); see also Margaret Jane Radin, Compensation and Commensurability, 43 DUKE L.J. 56, 65-67 (1993) (same).

${ }_{12}$ See Epstein, supra note 8, at 696 ("In dealing with a familial situation, [Raz] stressed the question of incommensurability of values but ignored the more important and pressing question of interdependent utility functions.").

${ }^{13}$ See id. 
more than time with his wife becomes "impossible" to ask; rather, the proper question is whether the husband and wife have "made other side transactions, present or future, so that the increment in wealth produces gains in utility to both of them in a fashion consistent with family affections and family obligations." ${ }^{14}$

What is most striking about these examples is that they all play upon the readers' shared intuitive sense that it is wrong to think in terms of exchanging money for some other valuable relationship or even to think of the formation of some relationships in terms of the "market" or "exchange" metaphor. For many of those who have any experience of college fraternity and sorority social life, however, the idea that dating and courtship are institutions of the marriage market-and that participants would be well-advised to recognize that they are part of a market-might well seem unremarkable. That the sense of awe and wonder provoked by our great Western mountains, rivers, and plains is not translatable into dollar terms would come as a surprise to real estate agents in the Rocky Mountain region, who have spent the last decade busily consolidating vast and hugely expensive private ranch lands. ${ }^{15}$ It may be uncommon for one neighbor to offer to pay another to mow her lawn, but it would be equally uncommon for the neighbor not to offer to pay her neighbor's son or daughter to do the job. In fact, many cultures require friends to make money gifts to each other on important religious and family occasions. ${ }^{16}$ That a husband would fail to consult his wife before taking a distant job, or that he would view his incremental salary as "his" money rather than as a joint possession, would hardly come as a surprise, I suspect, to many American wives and ex-wives.

The utility-maximization approach is, as Epstein argues, very flexible, and can be employed to explain the behaviors in all of these examples. Yet the issue they raise is not whether a particular behavior is or is not consistent with utility maximization, but rather why we should feel that the hypothesized ways of thinking about alternative actions are socially undesirable. We may agree with Epstein that it is

11 Id. at 697.

${ }^{15}$ See, e.g., Andrée Brooks, "Paradise" Seekers Drive up House Prices, N.Y. TIMES, Nov. $29,1992, \S 10$, at 5 (reporting a real estate "boom" in Idaho); Tim Cornwell, Cappuccino Cowboys Turn West Mild, OBSERVER (London), Aug. 13, 1995, at 18 (discussing the "suburbanisation of the American West").

${ }^{16}$ See Viviana A. Zelizer, The Social Meaning of Money 82-118 (1994) (recounting such practices among Jews and other early-20th-century American immigrant groups, and in contemporary Japanese culture). 
socially desirable for husband and wife to form bonds of interdependence, and that interdependent utilities may formalize such bonds in a useful way; nonetheless, we still may argue that the analytical objective is not merely to formalize such interdependence, but rather to explain whether it arises at all. Insofar as Sunstein's examples are designed to show that individuals maximize their utility subject to a constraint that certain harmful actions simply cannot be undertaken, the consequences of such a constraint may be to generate an incentive for willful self-delusion as to the consequences of one's actions, rather than a good-faith effort to determine whether harm will result. ${ }^{17}$ Compartmentalizing utility-with family in one category, work in another, and the environment in yet another-may not generate the results one might have expected originally.

What the examples tell us is not that there are incommensurable goods, but that (in the examples of the neighbor, the mountain, and romance) at least some of us prefer not to exchange some things for money, or at least not too explicitly. This is especially likely when what is to be exchanged (one's time together, in the case of the transferred spouse) is a relationship that conventionally is not exchanged for money on markets. Scholars who write about incommensurability frequently state that incommensurability is about the absence of a common metric, and that the particular metric really does not matter. ${ }^{18}$ However, the fact that their concrete examples almost always posit an exchange of something for money, an exchange that is socially or legally sanctioned, is no accident. What these examples demonstrate is that the claim that people cannot rank all alternatives

${ }^{17}$ Economists have begun only recently to uncover the positive implications of moral constraint. Matthew Rabin explores two alternative models of how an economic agent factors harm to others into her decisionmaking: direct preferences for avoiding harm (moral preferences), and self-interested utility maximization subject to the constraint that the probability of causing harm is not too high (moral rules). See MatThew Rabin, Moral Constraints, Moral PREFerences, and SELF-SERVING BIASEs 6-9 (University of Cal., Berkeley, Dep't of Econ. Working Paper No. 95-241, 1995). Rabin concludes that for given beliefs regarding the likelihood that harm will result from an action, the two approaches are identical, in that one always can construct a constrained, selfish utility function that generates precisely the same equilibrium choices as a moralistic utility function. See id. However, when people can manipulate their beliefs, an agent who abides by moral constraints will choose an informational signal that maximizes the probability of indicating that there is no moral conflict (no harm caused) and allows her to pursue her self-interest, rather than a disinterested strategy of acquiring all available low-cost information. See id. at 9-18.

${ }^{18}$ See, e.g., Matthew Adler, Incommensurability and Cost-Benefit Analysis, 146 U. PA. L. REV. 1371 (1998). 
along a single metric often blurs into the claim that people either do not or should not behave as if everything is for sale for money.

If I am correct in this interpretation, then the positive or descriptive issue raised by the incommensurability debate is not whether individual choices can or cannot be explained as the product of constrained maximization of a real-valued utility function over the space of potential actions; rather, the issue is how explicit market exchange affects the value of certain sorts of relationships. In this Article, I take a functional, economic approach to exploring this issue. Under this approach, ${ }^{19}$ the task is to explain how pricing certain relationships, or aspects thereof, in markets (money or market pricing) might affect both the individual and social value of such relationships. Such an approach, I hope to show, is likely to prove fruitful, not only in understanding the various behavioral phenomena that have been taken to illustrate incommensurability or commensurability, but also in understanding some of the fundamental issues in environmental regulation.

\section{A THEORY OF RESTRICTED EXCHANGE AND SOCIAL COOPERATION}

It is a commonplace observation that goods and services vary considerably in their characteristics. Whether an ingot is gold or silver may be determined quite quickly and inexpensively. Whether a person will make a suitable spouse may be much more difficult to determine, in large part because the suitor herself has only a very hazy idea of what she is looking for in such a person and understands that her own desires and objectives will be affected by the course of the relationship she initiates. As a general matter, markets do not perform very well when the goods or services placed on the market have unobservable characteristics or attributes that are an important element of value. This is true, for example, of the famous "lemons market" model. ${ }^{20}$ In such markets, the presence of unobservable, lowquality goods may cause buyers to discount the price they are willing to pay, which in turn drives out the highest-quality (highest-cost) providers, leading to an even greater discount, until the market unbundles (that is, where equilibrium fails to exist).

${ }^{19}$ See generally Jason Scott Johnston, Law, Economics, and Post-Realist Explanation, 24 L. \& SOC'Y REV. 1217 (1990).

${ }^{20}$ See George A. Akerlof, The Market for "Lemons": Quality Uncertainty and the Market Mechanism, 84 Q.J. ECON. 488, 492-99 (1970) (applying the lemons-market model to a variety of cases, including insurance and credit markets in third-world countries). 
That we in fact observe thick markets for goods of unobservable and variable quality, such as automobiles, is due to a variety of institutional refinements, such as the product-quality warranty, which allow high-quality providers to distinguish themselves from lower-quality providers. $^{21}$ One might be tempted to analogize human relationships to such goods or services (christened "experience goods" by economists). ${ }^{22}$ The value of a friend or a spouse is likely to depend upon that person's trustworthiness, honesty, and fidelity, qualities that may be signaled by actions, such as refusing to accept payments for good deeds and other benefits, that may seem disproportionately costly to confer. $^{23}$ In this light, although beneficial actions may be reciprocated, they can function as costly signals of valuable personal traits only if they are not exchanged for other items of value. Rather, these actions will be thought of as essential to the creation of particular relationships, and the question of whether one would accept money to perform them will, to quote Epstein, be "impossible" money for performing them would be to defeat their social purpose.

Such an account of what may be called "character signals" may explain why certain services or goods are provided with no expectation of compensation and, in fact, precisely because they will not be compensated. It does not, of course, imply that the beneficiaries of various services will be unable to rank them ordinally. I may be pleased by my neighbor's willingness to pick up my newspaper when I am away, but measurably happier if he also moves my trash cans for me. Even more significantly, the fact that some actions serve to signal one's character does not seem to explain why some exchanges not only do not occur, but also actually are punished severely when they do occur. There are straightforward and well-known economic explanations for many such prohibitions. To exchange babies for dollars in unregulated markets, as Chief Judge Richard Posner has argued, would be unacceptable due to the potential for external harm to such children. ${ }^{25}$ Surrogacy and prostitution may benefit individual women, but may well disadvantage women as a class by

${ }^{21}$ On warranties as signals of quality, see Michael Spence, Consumer Misperceptions, Product Failure and Producer Liability, 44 REV. ECON. STUD. 561 (1977).

22 See JEAN TIROLE, THE THEORY OF INDUSTRIAL ORGANIZATION 106 (1988).

${ }^{23}$ See Colin Camerer, Gifis as Economic Signals and Social Symbols, 94 AM. J. Soc. $\mathrm{S} 180, \mathrm{~S} 182-90$ (Supp. 1988) (modeling costly gifts as economic signals the value of which often derives from their inefficiency).

${ }^{24}$ Epstein, supra note 8, at 697.

${ }_{25}$ See RICHARD A. POSNER, ECONOMIC ANALYSIS OF LAW 165-70 (5th ed. 1998). 
reinforcing social equilibria in which women hold low-paying jobs. ${ }^{26}$ Such explanations of what is wrong with unregulated exchange do not (as the baby-selling example indicates) imply the normative undesirability of exchange per se. It is this failure that the incommensurability thesis addresses. As I have argued above, however, it does so in a circular and unconvincing way, by taking examples of our moral condemnation of certain sorts of contemplated exchanges as relevant to descriptive claims about the failure to have individual-level cardinal or ordinal rankings. ${ }^{27}$

An alternative approach, which I hope merely to outline here, is to develop a positive theory of restricted exchange, a theory that accounts for the effects of prohibiting money exchange. That is, we shall assume at first that money exchanges for certain relationships or aspects thereof are not allowed. By tracing the effects of such a prohibition, we then may be able to explain how such prohibitions have arisen.

Toward this end, note first that even though many human relationships do not involve the exchange of money, the common currency, they still depend strongly upon exchange. ${ }^{28}$ Prohibitions on money exchange are not tantamount to prohibitions on exchange per se. Marriage and friendship cannot work unless both parties feel that they are giving something to each other and getting something in return. Close personal relationships cannot work unless they are reciprocal. In such relationships, each person makes an emotional and informational investment, gradually coming to care directly about the well-being of the other, and gradually revealing private information about herself. Any "consistent imbalance" in these in-

${ }^{26}$ On surrogacy, compare Debra Satz, Markets in Women's Reproductive Labor, 21 PHIL. \& PUB. AFF. 107, 110 (1992) (arguing that "reproductive labor" markets reinforce gender and racial hierarchies), with Alan Wertheimer, Two Questions About Surrogacy and Exploitation, 21 PHIL. \& PUB. AFF. 211, 212 (1992) (arguing that "surrogacy contracts should be permitted" because "surrogacy is a form of voluntary and mutually advantageous exploitation"). On prostitution, see Jody Freeman, The Feminist Debate over Prostitution Reform: Prostitutes'Rights Groups, Radical Feminists, and the (Im)possibility of Consent, 5 BERKELEY WOMEN'S L.J. 75, 107-08 (1990) (arguing that, under today's social conditions, criminalization of prostitution "only makes life more difficult for prostitutes" by depriving them of their livelihood).

${ }^{27}$ See supra Part I.

${ }^{28}$ That these exchanges are "socially embedded" is beyond dispute. Thus, the economic approach can make a partial, but not complete, contribution to their explanation. See, e.g., JOHN DAVIS, EXCHANGE 9-27 (1992) (examining different kinds of exchanges). 
vestments will imperil the relationship. ${ }^{29}$ Actions are signals of such investments. A friend who is always too busy to help and a spouse who is too distracted to listen are failing to live up to their end of an implicit bargain. On the other hand, a friend who demands immediate reciprocation and a spouse who expects her wishes to be satisfied on demand are equally guilty of failing to understand the terms of their respective relationships. For although friendship, marriage, and similar close personal relationships involve exchange, the exchange takes place in a "time-lagged series of reciprocated transactions," so that when a good turn is done, repayment and reciprocity indeed are expected, but only with delay. ${ }^{30}$ Since money is not used to execute such exchanges, these relationships involve delayed, bartered exchange.

Relative to immediate money payment, delayed, in-kind reciprocity is risky. If one agrees to perform a service only if money is paid (either now or later), then one knows what one is getting. Money is money precisely because the cost of ascertaining what money will do is low. ${ }^{31}$ Under a barter system, by contrast, each side to a transaction must determine both the physical and market characteristics of the good or service. That is, to exchange bananas for oranges, the orange holder must be able to evaluate both the physical characteristics of the bananas she is offered, as well as what they will be worth to others in the market, in order to determine how many bananas per orange to accept. ${ }^{32}$ In a world with relatively few goods, such evaluations may be simple enough. But as the complexity of the economy and the number of goods and services multiply, it will become more and more difficult for traders to execute in-kind transactions. Without money, even the development of a market for middlemen who develop reputations for certifying the quality of various goods and services will be stunted. Without money, the middlemen would have to become expert in all the goods and services they might receive in payment for certifying the quality of others. ${ }^{33}$ Without money, asymmetric information about the physical and market qualities of goods

${ }^{29}$ GRAHAM ALLAN, FRIENDSHIP 22 (1989).

s. Id.

31 This point is central to the theory developed in Armen Alchian, Why Money?, $9 \mathrm{~J}$. MONEY, CREDIT \& BANKING 133 (1977).

32 This model, and the terminological distinction between physical and market attributes, is developed in Abhijit V. Banerjee \& Eric S. Maskin, A Walrasian Theory of Money and Barter, 111 Q.J. ECON. 955 (1996).

${ }_{33}$ See generally Alchian, supra note 31 (explaining the use of money in exchanges and its effects on the development of a class of specialist middlemen). 
will act as a tax on transactions, thus preventing many valueenhancing deals.

This economic explanation of why money dominates as a medium of exchange generates insight into the effects of prohibiting money exchange in close, personal relationships. Even if (as with contemporary dating and matchmaking businesses) one can pay money to get information about a potential spouse or companion, the restriction on money exchange within the relationship puts a premium on acquiring information about the potential mate. Since the relationship involves bartered exchange (or reciprocity, in more anthropological terms), each party has a strong incentive to learn about the human resources and capabilities of the other-what the other has to givebefore committing to the relationship. Since the bartered exchange typically will be delayed (that is, delayed reciprocity), each party has a strong incentive to learn whether the other person is trustworthy and will in fact commit to the relationship and provide what she has to give on fair terms. Both the value of human resources and the nature of the reciprocal commitment made by the parties inevitably will be highly idiosyncratic. Still, the requirement that friends retain a "longrun equivalence ${ }^{\$ 4}$ in their transactions may tend to favor friendships between persons from similar social circumstances. Differently, strongly gendered social roles may generate a pattern of exchange within the marriage relationship that is, at least in material terms, highly unequal. ${ }^{35}$

Therefore, the restriction on money exchange necessarily creates vulnerability and increases risk. ${ }^{36}$ In forming relationships within which exchange is delayed and in-kind, what one seeks is a good match between one's own needs and the resources of the other, and a partner who is trustworthy. In other words, prohibiting money exchange not only increases the costs of forming the exchangerestricted relationship, but also puts a premium on trust within it. Because exchange-restricted relationships are (relatively) costly to form, they are costly to end-since the cost of terminating a relation-

\footnotetext{
34 ALLAN, supra note 29, at 22.

${ }^{95}$ This is portrayed vividly by Zelizer, who recounts the ways in which the prohibition on money exchange within the household reduced wives' independent economic status when husbands became the sole source of household income in middle- and upper-class Victorian American households. SeeZELIZER, supra note 16, at 70-120.

${ }^{36}$ An important, implicit assumption is that promises to reciprocate in-kind within close, personal relationships are legally unenforceable. Fuller treatment of this assumption is a topic that must be left to a later day.
} 
ship is determined by the difficulty of substituting it with a new relationship. Parties to such relationships might well find the prohibition on money exchange to be a burden, an obstacle to transacting. Indeed, they might be tempted, as in the case of prostitution, to go outside the relationship and make money purchases of services conventionally provided within it. However, by so doing, they reduce the set of services exchanged within the relationship, thus reducing dependency upon it. "Dependency" may have a bad ring to contemporary American ears. But what it means, analytically, is that one's own actions are reciprocated in-kind by the other party to the relationship. To the extent that such reciprocity no longer is valued, because the reciprocal service is provided by some other, outside money exchange, commitment is lessened. As commitment falls, so too does the possibility of ensuring reciprocity within the relationship. One may threaten to or actually fail to reciprocate. Friends who renege on their engagements are at risk of seeing their own expectations disappointed. However, if those who renege are already buying whatever they need, then they have no need for the services so imperfectly exchanged within the relationship, and no longer are vulnerable to threats to diminish its depth.

This might seem to imply that restricting money exchange is simply inefficient. As the examples drawn from the incommensurability literature indicate, however, it is a common observation that although some people seek the services of prostitutes and attempt to buy friendships with money, many do not. Apparently, for many people, the value of being able to trust their intimates to reciprocate exceeds whatever temporary cost such imperfect and delayed exchange entails. Many people eschew money exchanges that would ineluctably destroy the trust they have built up in close relationships. Social and legal prohibitions of money exchange may simply reflect existing, efficient social practice.

That they do more than this-by punishing inefficient exchanges-may be understood by considering the effect on the victim of the betrayal of trust. For a person to develop the capacity to trust another, there must be both a time lapse between the exchange of goods or services, and reasonably clear expectations regarding what constitutes adequate or fair exchange. ${ }^{37}$ Marriage, friendship, and family create expectations that care and concern will be reciprocated.

${ }^{37}$ See Barbara A. Misztal, TRUST IN MODERN SOCieTIES 17 (1996) (describing the types of exchanges in which trust plays an important role). 
Through such relationships, a person learns what reciprocity means. This is a complex process of negotiating and constructing the terms of the relationship. If the other party does not feel that an act has been reciprocated adequately with sufficiently little delay, then the value to her of the relationship will begin to diminish. The convention of reciprocity is complex and must be learned. The convention of reciprocity, however, is, in more technical terms, the convention of cooperation. Exchange-restricted personal relationships are where one learns how to cooperate and to detect cooperation in others. It is in these relationships that the expectation of reciprocity, and the rationality of trust and cooperation, is greatest. For this reason, anything that lessens or diminishes the incentive to reciprocate within such a relationship will have an especially damaging effect. At the risk of sounding cliché, if one cannot trust one's parents, one's spouse, or one's friend, then whom can one trust? And if the signals of cooperative intent sent by these intimates are proven to be false, why should any signal of trustworthiness ever be taken seriously?

On this view, money-exchange restrictions lower the value of cheating in cooperative relationships by restricting the set of outside opportunities. It is not every relationship in which such restrictions are imposed, for the point of most relationships is not to develop trust, but rather to exchange goods or services. Yet the qualities of trust and reciprocal cooperation that are learned in our most personal relationships are of enormous social value in lowering the cost of market and money transactions. ${ }^{38}$ By forcing vulnerability and commitment in some relationships, restrictions on money exchange actually lower the social cost of forming and performing relationships that do involve money exchange. These restrictions are imposed and supported by social and/or legal sanctions, because they increase the cost of violating trust, and thereby support its development.

\section{RESTRICTED EXCHANGE AND ENVIRONMENTAL REGULATION}

In this Part, I argue that the effects of restricted exchange in allocating access to and relationship with collective environmental goods are similar to the effects of restricted exchange in allocating human relationships. By eschewing money prices, we increase the collective

ss See Michèle LAMONT, MONEY, MORALS, AND MANNERS 34 (1992) ("$[\mathrm{T}]$ rust ... acts as an important regulating mechanism in work situations where uncertainty is high. Trust is ... what makes it possible for people to work together in a productive way without being constantly on their guard .... ). 
vulnerability to the misuse of collective resources, and trust those who are given access to collective resources to reciprocate by returning collective benefits generated by that access. Trust, of course, may be violated. Just as with human relationships, however, allowing money to be paid in exchange for access to or relationship with collective resources actually will increase the incentive to violate trust. Additional problems with pricing arise from the fact that goods are held collectively. In particular, pricing is likely to exacerbate the difficulty of ensuring that the agent of the collective is faithful to her mandate in allocating access to the collectively held good. For all of these reasons, rather than pricing access to collective goods, we sanction their misuse (or overuse). After sketching this account, I briefly apply it to selected contemporary issues in American environmental law.

\section{A. Trust, Money, and the Value of Collective Environmental Goods}

In the United States, legal ownership of the external environment has followed a relatively simple and basic pattern. Air and water, as well as the land and the plants and animals on it, all were subject initially to collective ownership. Private ownership of land-acquired by possession and use, by sovereign grant, or by money exchangeconfers derivative private rights in the quality of the air above, the water on and below the land, and the animals that may pass through it. Collective ownership of an entire bundle of external resourcesland, air, and water-is the exception. Residual collective ownership of nonland resources, however, is the rule. ${ }^{39}$

This pattern of legal ownership of the external environment has set up a system of exchange relations. As a default rule, money exchange is the rule for land, and for land-derivative interests in collective resources. The residual collective interest in air, water, plants, and animals found on private lands, by contrast, generally has not been allocated via explicit money prices. Private access to or use of slices of pure collective ownership-as in the federal lands of the American West-likewise has not been allocated via money prices. Rights have been granted instead on a first-to-use basis, with fees deliberately set so low as to be unimportant to allocative decisions.

This pattern of ownership and exchange will strike even the most economically naive person as an inefficient giveaway. If collective

99 See JESSE DUKEMINIER \& JAMES E. KRIER, PROPERTY 11 (4th ed. 1998) (noting that "[l]andownership... commonly determines the ownership and control of a host of other natural resources"). 
interests in the external environment are not priced, then private users will not take adequate account of the potentially harmful effects of their use on those collective goods. This is true even of residual collective ownership of nonland resources, for even if nearby landowners have protected legal interests in air and water quality, interests that allow them to charge a price for degradation caused by some other landowner, their interests may not be the same as the "collective" interest. There inevitably will be, on this straightforward economic account, a nonpriced externality.

It is not, however, economic theory that makes this externality seem so obvious; rather, it is our contemporary use of private lands and collective resources. Industrialization, suburbanization, and strip-mall development make it difficult to conceive of any relationship between a private landowner and collective environmental goods other than one of rational degradation of the value of nonpriced collective goods. Yet, such was not always so, and is not so everywhere today. For many early white American settlers, their survival depended entirely upon resources that they did not own. ${ }^{40}$ When the whites first came to North America, they found indigenous peoples with an astoundingly detailed knowledge of their natural world, a world already changed greatly by the activities of those peoples. ${ }^{41}$ To the Native Americans, the notion that relationship to the external environment ought not, and indeed could not, be exchanged for money was a bedrock belief. ${ }^{42}$ By contrast, many Europeans came to America to find, develop, and exchange relationships with the land. ${ }^{43}$ The frontier, in fact, may be defined as the place where exchange has not yet (but soon will) come to dominate. ${ }^{44}$

${ }^{10}$ For a romanticized, and yet enthralling, novelistic account of such a relationship in frontier Florida, see PATRICK D. SMITH, A LAND REMEMBERED (1984).

"See, e.g., WiLlIAM CRONON, CHANGES IN THE LAND 54-55 (1983) (detailing the Native Americans' seasonal migration to find food); STEPHEN J. PYNE, FIRE IN AMERICA 71-81 (1982) (discussing the Native Americans' detailed understanding of fire and its agricultural value).

${ }^{42}$ See CRONON, supra note 41, at 162-63 (arguing that Native Americans were confused by Europeans' regard for land as an economic good).

${ }^{43}$ See Donald WORSTER, THE WEALTH OF NATURE 95-111 (1993) (describing the effect of the European business mogul in America).

14 The prominence of the frontier as a historical theme, especially in thinking about the American West, may be attributed in large part to Frederick Turner. See generally FREDERICK JACKSON TURNER, THE FRONTIER IN AMERICAN HISTORY (1920) (discussing American pioneers' ideals). For an introduction to how historical thinking has evolved since Turner, see DONALD WORSTER, Beyond the Agrarian Myth, in UNDER WESTERN SKIES 3 (1992). 
On the frontier, vulnerability to the natural environment was at its greatest. Early agricultural and range use of the land did not lessen dependence upon collectively held resources, but rather increased it. The very idea of "settling" implied a long-term relationship with collectively held resources. Selling the land for money was not an easy thing for frontier settlers to do, for the land represented a life, a repository of memory and tradition to be passed down through the generations, rather than a commodity tradable through the market. $^{45}$

On this view (which I cannot hope to defend fully here), unrestricted money exchange in land arose as a way to facilitate long-term relationships of trust and mutual dependence between landowners and the collectively held, nonpriced environmental goods that played such a large role in fixing the value of their lands. It was precisely to create a sense that these collective goods were entrusted to private landowners that they were included in the landowners' (commonlaw) package of legal rights. In theory, exchanging land for money might well enhance a landowner's incentive to care for the air, water, and other collective goods, for by enhancing the value of those goods, the landowner also would increase the market value of her land.

This may be true in theory, but in practice, matters are much more complex. Just as money exchange inevitably weakens the incentive to wait for delayed, reciprocal in-kind benefits in personal relationships, so too does money exchange for interests in land weaken the incentive to make idiosyncratic, long-term investments in a place. With money exchange, there is no need to become expert in evaluating the qualities of a place so as to determine its value relative to another. One may accept instead the much less risky, easy-to-evaluate common currency. With free exchange for the common currency, the possibilities of exchange magnify, and as they do, dependence on the land in its environment diminishes.

This is not to suggest that interests in land ought not to be freely exchangeable for money. After all, although we may deem some services and personal relationships to be beyond the realm of money exchange, most services can be purchased for cash. However, just as with relationships among people, there must be some relationships with the natural environment that are removed entirely from the money-exchange mechanism. These relationships with the external,

${ }^{45}$ On the relationship between tradition, memory, and the land, see SIMON SCHAMA, LANDSCAPE AND MEMORY (1995). 
nonhuman world are not freely exchangeable precisely to force us into relationships of mutual dependence with the environment. When all aspects of a slice of the external world-including land-are held collectively and not exchangeable for money, individual returns must take the form of a stream of in-kind benefits. By forbidding money to be exchanged for any aspect of the collectively held external world (including, importantly, any product of individual interaction with it), we force the same sort of costly search, matching, and barter process that occurs with human friendship and marriage. We obligate individuals to find those collective resources that best suit their own preferences, resources, and capabilities. They must seek those resources that are best able to reciprocate the individuals' own cares and concerns, not in terms of money, but in experience. As in our most treasured human relationships, our relationships with collective environmental goods are where we learn about the complexity of the external environment, and about how to negotiate a cooperative relationship with that environment.

Furthermore, just as we learn about trust from our closest personal relationships-a lesson of enormous value in market exchanges-the learning that takes place when we interact with collective environmental goods may carry over to influence how we use and exchange land. By learning to value collectively held environmental goods, we begin to appreciate the residual collective interests that attach to private land ownership. However, for this valuable spillover to take place, interaction with collective environmental goods must be dense and repeated. Without an adequate opportunity to relate to collective environmental goods, the social benefits of such interaction will be diminished. As the next subpart explains in greater detail, it is theoretically impossible to use money prices to allocate the opportunity to interact with collective environmental goods in a way that maximizes these social benefits.

\section{B. The Economics of Collective, Unpriced Environmental Goods}

Under the conventional economic approach, environmental problems arise when an aspect of the environment, such as the atmosphere or the oceans, is under common ownership and hence subject to what is known as the "tragedy of the commons." tragedy of the commons occurs when access to a resource is free to

${ }^{46}$ Hardin, supra note 1 , at 1244. 
all, but increased use of the resource by one person (whether positive, as for grazing sheep, or negative, as for dumping waste) imposes costs on other users. ${ }^{47}$ Under such conditions, the resource is overused. Yet, over seventy years ago, Frank Knight pointed out that the commons problem has nothing to do with common ownership, but is instead a simple consequence of the failure to charge an appropriate access fee for the use of the resource. ${ }^{48}$ In other words, the commons problem arises because the relationship between a resource user and the resource is not given an appropriate money price.

That a resource is owned by a group or collectivity thus has no direct relationship to the commons problem. Indeed, although the failure to exclude individual users and to create individual rights in a resource itself may have an economic explanation, ${ }^{49}$ there are plenty of examples of relatively small collectivities that manage to allocate their collective resources via price and nonprice mechanisms in surprisingly efficient ways. ${ }^{50}$ The commons problem is institutional in that it arises only because collective institutions are not designed to facilitate efficient collective action. The difficulties to be overcome in designing such institutions are well known. Some of the owners may have little concern for the resource, so little, in fact, that they are unwilling to see that it is cared for (which in the conventional account is the reason for common ownership in the first place). Conversely, other members of the "common" may care so much about the

${ }^{47}$ For a path-breaking technical approach to this problem, see Martin L. Weitzman, Free Access vs Private Ownership as Alternative Systems for Managing Common Property, 8 J. ECON. THEORY 225 (1974).

${ }_{43}$ See Frank H. Knight, Some Fallacies in the Interpretation of Social Cost, 38 Q.J. ECON. 582, 586 (1924), reprinted in FRANK HYNEMAN KNIGHT, THE ETHICS OF COMPETTTION AND OTHER ESSAYS 217, 220 (1935). Technically, the problem arises due to the diminishing marginal product of the variable factor. Under free entry, the average product of the variable factor is equalized across fixed sites, which necessarily implies supra-optimal use of the more valuable sites.

${ }^{49}$ Economic explanations point to the cost of administering private-ownership regimes. See, e.g., ELINOR OSTROM, GOVERNING THE COMMONS 13 (1990) (discussing the problems involved in privatization); Paul Seabright, Managing Local Commons: Theoretical Issues in Incentive Design, J. ECON. PERSP., Fall 1993, at 113, 117 (suggesting that the value of formal mechanisms of collective-resource management like privatization depends on the effectiveness of informal mechanisms).

${ }^{30}$ See OSTROM, supra note 49, at 58-102 (presenting various case studies of communal-resource allocations). 
resource that they wish it all to themselves, refusing to grant access or regulating uses to allow only those uses that they themselves prefer. ${ }^{51}$

It is, however, incorrect to label as "problems" the obstacles to efficient collective action. If we are to make a proper analytical start, it must be by asking why a collective, exchange-restricted relationship with some aspect of the external environment is adopted over other alternatives. Collective ownership and restrictions on how the collective allocates relationships to collective holdings are related and yet distinct. In this Article, I take collective ownership as a given and explore the reasons why sanctions, rather than prices, emerge as the means of regulating such a collective good.

It is an important, but often neglected, result in environmental economics that even if the agent of the collective is able to charge a money price that accurately reflects the costs imposed on others by any one person's access to the resource, so that the access price will encourage economically efficient resource use, all those who have been using the resource without paying such a price will have a lower money return under such a pricing scheme than they have been enjoying under inefficient (and unpriced) overuse. ${ }^{52}$ This fails to hold only if the proceeds from the access fee are redistributed to the current (or previous) users. Thus, as the size of the collectivity and the cost of administering the collective-pricing mechanism increase, so that it is no longer possible to return the access fees lump-sum to the previous users, previous users inevitably are made worse off by the imposition of the pricing regime. In this way, the decision not to use prices in allocating the collective resource is effectively a collective decision to favor existing users or potential future users.

This may (and often does) generate the suggestion that the goal of encouraging trust and a long-term relationship with collective environmental goods is a fiction employed by those who currently are using the resource without paying a money access fee to oppose an efficient fee that they fear (correctly) will reduce their money return. ${ }^{53}$ Restricting money exchange for access to or relationship with

${ }^{31}$ See James E. Krier, The Tragedy of the Commons, Part Two, 15 HARV. J.L. \& PUB. POL'Y 325, 337 (1992) (arguing that one cannot advocate collective coordination as a solution to the commons problem, since it is the cause of the problem).

${ }^{52}$ See Weitzman, supra note 47, at 225; David de Meza \& J.R. Gould, Free Access vs Private Ownership: A Comparison, 36 J. ECON. THEORY 387 (1985) (extending and qualifying Weitzman's results).

${ }_{3 s}$ Oddly, even though proposals to establish catch quotas or entry restrictions and fees often grandfather and do not cover existing fishermen, fishermen tend to oppose such proposals, and to support controls-such as season closures and fishing-vessel 
collective resources, it may be argued, is simply a way of ensuring that an inefficient distribution is not upset in place of a more efficient redistribution of relationship. Pricing a resource, it may be argued, is the only way to ensure that it is valued properly and not overused.

This, however, ignores the crucial role of information in collective-pricing decisions. Collective provision raises two fundamental incentive problems: (1) ensuring that individuals truthfully reveal how they value the resource, and (2) ensuring that the agent of the collective allocates relationships to the resource in a way that reflects the collective valuation of alternative relationships with it. Both of these problems are complicated by the fact that although the external environment survives the duration of any one person's relationship with it, it may be altered profoundly by that relationship. The question is how prices versus nonprice sanctions as allocative mechanisms compare along these dimensions.

\section{Prices, Qualitative-Information Revelation, and the Principle of Localism}

If, as I have argued above, the decision to provide an environmental good as a collective good is triggered not by the cost or infeasibility of creating exclusive, individual property rights, but rather by the perceived social benefits from long-term, cooperative relationships with the environment, then the economic problem for a faithful agent of the collective will be to determine when the benefits from such collective ownership outweigh the costs. Moreover, the agent must decide how to allocate access to or relationship with the collectively held resources. Prices are attractive because they promise to solve both problems. If the agent could determine how much people benefited from alternative collective goods, and then (assuming at least limited exclusion is possible) allocate access to or relationship with those goods based on the stated willingness to pay, both problems would be solved. Any such mechanism for discerning individual valuation must, however, describe the qualities of the resource that is under consideration-that is, people cannot be expected to come up with meaningful responses when asked how much they will pay for access to a good unless the qualities of the good are described. The agent's objective, of course, would be to elicit truthful statements of

restrictions-that seem to redistribute inefficiently the total catch. See Jonathan M. Karpoff, Suboptimal Controls in Common Resource Management: The Case of the Fishery, 95J. POL. ECON. 179, 180 (1987). 
individual valuation. One of the important results of contemporary information economics is that for the agent to induce truthful revelation, she would need to offer a price-attribute menu that degraded quality at the lower end of the menu. ${ }^{54}$ With money prices, if a person's revelation that she values an attribute highly means that she would have to pay a great deal for it, she will have an incentive, however well-meaning, to understate her valuation of the attribute and pay a lower price, thereby retaining economic rents generated by her private information regarding her own values. To offset this incentive, it is necessary that the provider offer unduly low-quality opportunities to those who state a low valuation of quality. Under a moneyprice regime, the agent cannot both discern individual values and allocate qualities efficiently given those values.

Now it is true that this revelation problem arises only because the agent is attempting to map prices onto resource quality according to the revealed valuation of quality. On the other hand, under a regime of money prices, weakening the relationship between the price-quality provided and stated value inevitably weakens the incentive to reveal value truthfully, lowering the level of quality provided. This implies that to allocate access to and relationship with a collective resource faithfully, in accordance with the members' express valuation of alternative qualitative opportunities, it may be necessary to sever any direct connection between their stated valuation and the costs they must actually incur to realize those values. However, if one asks how much a person would pay to realize such an opportunity, but the person knows full well that she in fact never will have to make such a payment, there is no reason not to overstate value. On the other hand, to ask a person what qualities she cares about, and then to charge a high money price for those she cares about most, is to create an incentive to understate value. ${ }^{55}$

Consider now the alternative of asking a person what she cares about, but then allocating her access to environmental relationships according not to her stated concern, but rather to the cost to others of her realization of that relationship. ${ }^{56}$ Were there only one sort of

${ }^{54}$ For technical demonstration of this result, see Eric Maskin \& John Riley, Monopoly with Incomplete Information, 15 RAND J. ECON. 171 (1984).

${ }^{55}$ This point is made nicely in RICHARD T. CARSON ET AL., THE THEORY AND MEASUREMENT OF PASSIVE USE VALUE (University of Cal, San Diego, Dep't of Econ. Discussion Paper No. 95-01, 1995).

${ }^{56}$ As this allocation method was independently discovered and presented in Edward H. Clarke, Multipart Pricing of Public Goods, 11 PUB. CHOICE 17 (1971), and 
relationship to the environment, and everyone were interested in having such a relationship, such a scheme might induce successfully the revelation of values. But there are many different sorts of relationships to the environment, just as there are many different sorts of relationships among people. Even if our collective agent were able to compile a list of all such potentially valuable relationships, not everyone would wish to participate in all of them. Indeed, some people inevitably would find some relationships so distasteful that they not only would refuse to be part of such interactions, but would view them as being harmful to other relationships. Toward these they would express extreme negative valuation; and yet since they themselves would never engage in such an interaction, they would bear a cost only if we expanded our scheme to require a price to be paid for excluding someone else's relationship to the environment as well as for maintaining one's own. But even if we agree that exclusion is to be determined simply by adding up individually expressed dollar valuations of benefit or harm, making payments to those whose desired relationships are excluded under such a calculus would create an incentive to devise and threaten new and ever more harmful relationships merely to garner payments (which might truly be called greenmail) for not having them. The only way to avoid this problem would be to make a prior determination that excludes certain qualities or attributes of environmental relationships as being of potential individual value. Such a determination then cannot be based on stated or express individual values.

This analytical exercise has an important set of policy consequences. As the relationships between members of the collective and the resources the collective holds become more fragmented and heterogeneous, it becomes increasingly difficult and eventually impossible to devise any kind of price-based mechanism that will elicit truthfully how individuals are affected by one another's relationships. When all members of the collective engage in the same activities, they all perceive the activities as beneficial and worthy of regulating appropriately; but when some members perceive the activities as generating no benefits to them, they have an incentive simply to ban them. Even worse, perhaps, the more distinctive and nonoverlapping are individual relationships to the environment, the greater the incentive 
under a collective-pricing mechanism actually to produce new, generally harmful relationships.

Another way of putting this general result is that the viability of collective pricing depends upon the viability of community. Inasmuch as smaller collectives are likely to share many of the same relationships to a collective resource, this may be termed the principle of localism in collective pricing. Only a collective in which individuals have similar relationships to and feelings toward their collectively held resources can possibly succeed in eliciting individual valuations. Under such circumstances, a collective-pricing mechanism can be very useful to a faithful agent of the collective in determining which relational features-intensity of use or precautions to avoid unnecessary harm to inherited (or natural) attributes-will best serve the collective interest.

There is a further policy corollary: Collective pricing cannot be used to determine which uses or relationships should be permitted among a class of widely differing and conflicting uses. The greater the variation in potential uses or relationships, the greater the incentive to misstate individual valuations under even the best collective price-based revelation mechanism.

\section{Science, Incentives, and the Limits of Localism}

Just as the complexity of individual interaction with the collectively held good dooms collective-pricing mechanisms as a way of eliciting individual value ex ante, so too does such complexity frustrate attempts to attach prices ex post via a liability regime. ${ }^{57}$ The observable qualities of a particular collective resource may be altered between the time a particular person begins and ends her relationship with that resource. Determining, however, whether that person's relationship has effected those changes will be more difficult, for the more complex her relationship is to the resource, the greater the number of other users, and the greater the variation in uses. If, for instance, all users are loggers, and we observe and measure a decline in forested acres, then we may be able to determine quite easily each logger's separate contribution to the overall decline in forest acreage. If, however, the collective has allowed logging, agriculture, and industry all within close proximity to the forest, and we observe that many trees are diseased and beset by insect infestation, then we may be

${ }^{57}$ See Cooter, supra note 2, at 1523 (postulating the idea that ex post damages may be thought of as prices). 
unsure of the precise way timber harvesting patterns have interacted with the chemical by-products of agriculture and industry in causing forest decline. Such uncertainty is, moreover, likely to be greater the more complex is the ecological relationship among collective resources. Were collective resources isomorphic to ecosystems, and ecosystems biologically distinct, then we might hope to identify, over time, the separate impact of even very complex human uses. But when collective resources are not isomorphic to biologic communities, the impact of human relationship with a particular collective resource cannot be identified without taking into account human interaction with other, biologically related resources.

Thus, even if our community members were to share many relationships to the forest (everyone benefited from logging, farming, industry, and recreational use of the forest, making a collectiverevelation mechanism in principle possible), they could not attach a value to alternative styles or levels of human relationship unless they were first informed as to how alternative levels or styles affected those attributes. This would become increasingly difficult, and eventually impossible, as the complexity of human interaction and disparity between collective resources and biologic communities increased. Localism-the organization of collective-ownership units designed to correspond as closely as possible to shared human interest in the environment-ameliorates the problems of collective-revelation mechanisms caused by complex and differing human interactions with the environment. But localism tends to worsen the disparity between human and nonhuman communities. As localism strengthens, it becomes increasingly difficult for the collective to identify how its members' interactions with the collective resource affect its observable attributes, thus frustrating attempts to attach a dollar valuation to those interactions.

This is not, it should be stressed, an argument about scientific knowledge, but rather one about collective incentives. The ability to generate scientific information regarding the relationship between individual uses and environmental impact is not necessarily affected by the fragmentation of units of collective human ownership from natural ecosystems. Rather, the difficulty is that as the number of human collectives increases, so too does the incentive for each collective to produce science indicating that the adverse or unwelcome impact on its collective resource has been caused by activities permitted by other collectives. To solve this interjurisdictional problem, we would require a super-mechanism, designed to elicit not only how 
each collective values various attributes of its collective resources and the effect on those resources of activities conducted elsewhere, but also its best, truthful scientific assessment of the impact of its own activities on the resources held by other collectives.

This model implies the economic desirability of a global definition of the community of environmental scientists: It is only with such a universal scientific jurisdiction that we can hope to overcome the incentive problems besetting the truthful elicitation of scientific assessments. Yet the demand for such assessments-that is, the need to determine what has caused discernible environmental impact-is, of course, a function of a particular community's collective valuation of its own environmental goods. Scientific study of the environment is just another of many human interactions with the environment. A global collective-choice mechanism would need to elicit the valuation of such scientific activity, but such activity affects the allocation of prices under the mechanism by determining causality. Hence, no individual could assess the valuation of scientific activity without first determining the effect that science is likely to have upon the prices she has to pay under the mechanism. This is something that cannot be known until the scientific activity has taken place. Even worse, were it known or anticipated in advance, an individual's valuation of scientific activity would depend on the effect such activity had upon her prices under the mechanism. If she expected science to be costly to her, she would have an incentive to undervalue science severely. The only way to price science under such a mechanism, then, may be to conceal how it is used or what it might find. At a fundamental, conceptual level, science cannot be evaluated under a collective-price mechanism.

\section{Prices, Sanctions, and the Social Value of} Collective Environmental Goods

Complexity and variation in human interaction with the inherited environment thus create insuperable problems for price-based collective-ownership systems. Such systems attempt to elicit individual valuations of observable, measurable environmer tal attributes, but individual incentives to reveal such values decrease with the scope of collective ownership, even though the ability to discern the relationship between individual actions and collective attributes increases with such scope. The problem of designing a method for a pricebased mechanism for valuing environmental change is, conceptually, unsurmountable. 
These largely negative results regarding the viability of collectivepricing mechanisms carry both positive and normative implications for how decisions to provide and regulate collective environmental goods actually may be made. When all members of the collective know at the time the initial decision regarding collective provision is made that relationships to that good will not be negotiated via money exchange, demand for collective provision will be strongest among those who already possess the resources necessary to realize benefits from the collective good. In some cases, such as air, this will entail consensus collective provision. In other cases, such as parks and natural areas, collective provision will be supported by those who already are making nonmarket use of the resource. Those who wish to realize the market value of the resource will support collective provision if and only if the agent of the collective allocates access via a nonprice mechanism, but then allows the free exchange of some of the fruits of access. Such a scheme, however, is no different than allowing the unbundling of our closest human relationships. The reason services provided by friends and spouses are not compensated in the common currency is that such compensation cuts the incentive to wait for in-kind compensation, thus lessening dependence-the very dependence that compels the negotiation of trust. In the same way, allowing users of collective resources to sell the products of their interaction with the collective resources-the timber they cut or the crops they grow using collectively provided water-creates an opportunity for outside compensation in the common currency, which lessens, if not destroys, any need to wait for in-kind compensation.

As a positive matter, this model therefore explains the intuitive reaction of Sunstein ${ }^{58}$ and others that the sense of awe and wonder we perceive upon viewing our great, collectively held natural resources indeed may be related to the fact that the right to such an experience may not be sold for cash. Just as offering to pay money in exchange for a friend's help signals rejection of a future obligation to reciprocate in-kind, so too does the collective agent's sale of access to collective environmental goods signal that the user is under no further obligation to reciprocate the benefits provided by such access by helping to care for and conserve those goods. The fact that goods are collectively held is, on this view, crucial: When a resource is individually owned, we look to the owner to protect and enhance its value; but the value of a collective good is determined by the extent to which

${ }^{3 s}$ See Sunstein, supra note 4, at 780. 
individual members of the collective feel that they owe something in return for its provision. This indebtedness is worked off by spending time, energy, and money to express one's individual valuation, an expression that takes place not only in individual use, but also in public participation via voting, lobbying, and interest-group membership. The institutional problem of free-riding posed by collective provision is precisely the reason that collectively provided environmental goods are not sold off for money: The free-rider problem is overcome inasmuch as individuals feel an obligation to take costly action to reciprocate past benefits and ensure the viability of future benefits.

For this same reason, prohibiting money from being exchanged for access to collectively held environmental goods increases the risk of inefficient rent-seeking behavior. In particular, the model condemns the very common American practice of providing goods collectively but then allowing private users of such collective goods to sell products of their use. Users who are allowed to commodify the product of accessing collectively held environmental goods necessarily will generate higher money returns from their access than will those who are looking to the future existence of the resource for their return. When we clarify what is to be gained from collective provision, we can see that there are probably far too many collective environmental goods in the United States provided simply to subsidize private market activity rather than to encourage the development of a cooperative social engagement with the external environment.

Exchange-restricted collective provision thus promises benefitsthe creation of private incentives for costly action to protect collectively provided environmental goods-but has costs as well-the creation of an incentive for rent-seeking under the guise of such "protective" efforts. The legal problem is to find a regulatory system that maximizes the expected net benefits from such collective goods. The answer, I believe, does not lie in making the individual user liable for the harm caused by individual interaction with or use of collective resources, for as argued above, such a scheme amounts to an ex post money-price mechanism. Moreover, as illustrated by the contemporary debate over Superfund, the complexity of environmental causation generates enormous transaction costs, either directly (in causation determinations) or indirectly (in attempts to shift the liability among potentially responsible individuals). Such individual liability must remain a secondary regulatory tool. Rather than pricing environmental harm, we must rely upon collective responsi- 
bility for environmental use. Such a scheme creates an incentive for individual members of the collective not only to monitor use, but also to report their observations to the collective agent. Monitoring, after all, is costly. Monitoring is not an end in itself, but rather a means of identifying those uses that are suitable for sanction. By making the continuing permissibility of existing uses contingent upon the communicated collective response to alternative uses, rather than on the payment of a certain sum of money (either ex ante or ex post), the exchange restrictions imposed on collectively held environmental goods manage to ensure that users will internalize certain effects of their use on other members of the collective.

Purely as a theoretical matter, the ideal or "first-best" pattern of internalization under collective nonprice regulation will look very different from the internalization ideal under a money-price regime. Precisely because individual interests in collective environmental goods are so diverse and conflicting, regulatory fine-tuning is economically undesirable. With collective goods, incentive compatibility is provided by a rule that says the good will not be provided unless there is clear evidence that the potential benefits from such provision are large and far exceed the costs. This both raises the cost and lowers the expected return to individual efforts to lobby for new collective goods. With the extent (rather than depth) of support driving the decision to provide a resource as a collective unpriced good, those individuals who demand collective provision simply as a means of getting private goods for free will face especially low chances of success.

The need to elicit truthfully individual perceptions of collective value constrains not only the initial determination of collective environmental goods, but also their subsequent regulation. Because the collective agent cannot hope to calibrate uses precisely, the best that the agent can do is to identify and sanction those uses that are sure to injure collective values. Apparent gross or severe departures from collective norms regarding use of the environment are, on this view, sanctioned not because they are known to cause injuries of comparable magnitude, but because only gross departures from collective norms regarding use are known almost certainly to cause some degree of injury. ${ }^{59}$ We condemn our neighbors for putting our parks and shared resources to clearly impermissible uses, not because we are

${ }^{59}$ The theory is set out in detail in Jason S. Johnston, Punitive Liability: A New Paradigm of Efficiency in Tort Law, 87 COLUM. L. REV. 1385 (1987). 
sure that there is great harm from such use, but because the lessons of time and tradition teach that there surely will be some harm. The presumptions of tradition are not irrebuttable, but they are presumptions nonetheless. Because the decision to sanction only gross violations is an instrumental decision, rather than a reflection of its certain moral culpability, the sanction only needs to reflect instrumental or deterrence concerns rather than a moral judgment of culpability.

As an immediate corollary, one would expect that violations in the character or type of use made of collective resources will be treated very differently from violations in the level or quantity of use. ${ }^{60}$ Judgments of moral culpability likely would be found fully appropriate when a use forbidden entirely because of its perceived harmfulness is undertaken. If personal watercraft are forbidden on public lakes, or dumping is prohibited in public parks, then violators of such prohibitions certainly will be judged as having committed a wrong: The public prohibition on any level of such uses expresses the public judgment that such uses are invariably harmful. When, by contrast, an industrial facility is found to have exceeded permissible effluent standards by a relatively small amount, a resulting sanction does not express any clear judgment that such an overage is in fact unduly harmful. Similarly, if that same facility were found to have antipollution devices that were not well-maintained, the appropriate sanction would be lower than if it had been found to have failed entirely to install the devices.

As this suggests, a crucial difference between prices and sanctions is in the latter's usefulness in facilitating reputational penalties. Small collectives typically enforce their use restrictions through nonlegal, collective sanctions, the paradigmatic instance of which is ostracism or exclusion. ${ }^{61}$ Providing and regulating collective goods at the state or national level does not mean that exclusion from particular, local supplies of those goods becomes infeasible. Rather, the difficulty is in gathering and transmitting to local communities verifiable information about an economic actor's past history of resource uses and abuses. Under a pricing regime, the fact that an actor has paid taxes or fees in the past is not informative as to the quality of her past

${ }^{60}$ For a wonderful, recent realization of this prediction, compare the majority and dissenting opinions in United States v. Weitzenhoff, 35 F.3d 1275 (9th Cir. 1994).

${ }^{61}$ For case studies, see MAKING THE COMMONS WORK (Daniel W. Bromley ed., 1992); THE QUESTION OF THE COMMONS (Bonnie J. McCay \& James M. Acheson eds., 1987); and David Feeny et al., The Tragedy of the Commons: Twenty-Two Years Later, 18 HUM. ECOLOGY 1 (1990). 
resource use. It is, indeed, one's right under a regime of prices or fees to lower collective values through one's own use, provided that one pays the price. When, by contrast, sanctions have been imposed for large departures from permitted uses or use levels in the past, there is verifiable evidence that the actor has been guilty of at least some kind of violation (even though the magnitude of past violations may remain somewhat uncertain). Exclusion can be credible and effective if and only if there is some way of labeling past violators. Sanctions perform this labeling function; prices do not.

A final, related point is that the choice between sanctions and prices is likely to be especially important when resources are much in demand, so much so that their economically optimal use may be close to a level at which their self-renewal is in doubt. There is no difficulty when this critical level is known with certainty, but when, as is typically true, the critical level is uncertain, a pricing regime easily may jeopardize the survival of the resource. Under a regime of prices, a particularly hot summer's high demand for energy to run air conditioners will result in high levels of output and (priced) emissions; under use controls backed by sanctions, the level of emissions will be fixed (even though under a regime of tradable quotas, the price will rise).$^{63}$ The credibility of both legal and extralegal sanctions will be enhanced by a perception that limits on resource use are critical to the survival of the collective good.

\section{Prices, Sanctions, and the Costs of Collective Agency}

The collective decision to adopt sanctions rather than prices in allocating rights to collective goods is explicable also in terms of its effect on the incentives of the collective agent given responsibility for the collective resource. The agency problem, simply put, is how the members of the collective are to determine that what the agent says is the best use of the resource really is best, rather than just that which maximizes the selfish interest of the agent. With a commonly owned resource, the objective is to ensure that access to the resource will be granted if and only if the collective is better off granting the access and receiving what is offered in exchange by the applicant than it

${ }^{62}$ This point has been made in a more general context by Robert Cooter. See ROBERT D. COOTER, LAWS AND PRICES: HOW ECONOMICS CONTRIBUTED TO LAW BY Misunderstanding MORALITY (University of Cal., Berkeley, Program in Law \& Econ. Working Paper No. 943, 1994).

${ }^{63}$ See Martin L. Weitzman, Prices vs. Quantities, 41 REv. ECON. STUD. 477, 477 (1974). 
would be were the application denied. As argued earlier, ${ }^{64}$ the economic approach suggests that the problem with making collective decisions about resource access is in finding a representative who cares enough about how the resource is used to expend effort to enhance its value, and yet not so much about it that she will attempt to appropriate all of its value for herself. The problem, in economic terms, is one of agency costs. ${ }^{65}$ The problem with allowing such an agent to exchange access to the resource for money is that it is difficult to determine where the money goes, and without such a determination, it is impossible to verify that the collective in fact has been made better off by virtue of the exchange. ${ }^{66}$ This is especially so when, as under a pricing scheme, the level of the activity directly increases the monetary return to the agent. Under such a scheme, the agent has an incentive to increase the level of the activity merely to increase revenues via the pricing mechanism. ${ }^{67}$ What is needed is a scheme that makes the agent's return relatively invariant with respect to violations of the permissible level of activities, but increases her return with the number of detected violations. Such incentives are provided by the regime of sanctions.

\section{APPLICATIONS}

The analytical framework presented here may be applied to a wide variety of contemporary issues in environmental regulation. Here, I have space to present merely a few incomplete illustrations of how such applications would proceed.

64 See supra text accompanying note 51 .

${ }^{65}$ See Michael C. Jensen \& William H. Meckling, Theory of the Firm: Managerial Behavior, Agency Costs and Ownership Structure, 3 J. FIN. ECON. 305, 308-09 (1976) ("We define agency costs as the sum of: (1) the monitoring expenditures by the principal, (2) the bonding expenditures by the agent, (3) the residual loss .... [A]gency costs arise in any situation involving cooperative effort ... by two or more people ....").

${ }^{66}$ Cf. id. at 309 n.10 (" $[\mathrm{T}]$ he existence of positive monitoring ... costs will result in the manager of a corporation possessing control over some resources which he can allocate... to satisfy his own preferences.").

${ }^{67}$ For a similar discussion of this problem, see Wallace E. Oates, Pollution Charges as a Source of Public Revenues, in ECONOMIC PROGRESS AND ENVIRONMENTAL CONCERNS 135, 140-45 (Herbert Giersch ed., 1993). 


\section{A. The Contingent-Valuation Controversy}

Under Superfund, the issue of how to value damages to collectively held resources has arisen. ${ }^{68}$ Courts have found a congressional preference for restoration cost as a measure of natural-resource damages under Superfund. ${ }^{69}$ At the same time, however, they have held that both the use and nonuse value of such resources may be compensable under that statute. ${ }^{70}$ There are a variety of ways to measure the lost-use value caused by damage to natural resources. ${ }^{71}$ Measuring the value that people derive merely from the existence of a commonly held resource is, however, more difficult. Even if the state charges a fee for accessing and using commonly held resources, such a fee bears no necessary relationship to the total collective valuation of the resource and its continued existence. Whether we call it nonuse value, preservation value, bequest or stewardship value, or inherent value, there is now quite widespread agreement that there is an element of value that is not captured by the prices or fees charged to use a commonly held resource.

How we might measure such value is, however, a topic of enormous controversy. ${ }^{72}$ Since people do not pay a market price for nonuse value, we cannot look to the market for valuation estimates. What has arisen instead is the practice of contingent valuation. ${ }^{73}$ Under

6s See Comprehensive Environmental Response Compensation Liability Act (CERCLA) of 1980, 42 U.S.C. $\$ 9607$ (a) (C) (1994) (indicating certain types of damages that are recoverable); Alaska Sport Fishing Ass'n v. Exxon Corp., 34 F.3d 769, $772-$ 73 (9th Cir. 1994) (discussing the valuation of damages); Ohio v. Department of the Interior, 880 F.2d 432, 438 (D.C. Cir. 1989) (holding a regulation limiting the damages recoverable contrary to congressional intent and therefore invalid).

${ }^{69} \mathrm{See}$ Ohio v. Department of the Interior, $880 \mathrm{~F} .2 \mathrm{~d}$ at 450 ("Congress intended restoration costs to be the basic measure of recovery for harm to natural resources.").

${ }^{70}$ See id. at 463-64; see also Thomas A. Campbell, Economic Valuation of Injury to Natural Resources, NAT. RESOURCES \& ENV'T, Winter 1992, at 28, 30 (discussing a case in which the court accounted for both use and nonuse values in calculating damages).

"See generally EcONOMIC VALUATION OF NATURAL RESOURCES (Rebecca L. Johnson \& Gary V. Johnson eds., 1990); A. MYRICK FREEMAN III, THE MEASUREMENT OF ENVIRONMENTAL AND RESOURCE VALUES 141-98 (1993); MEASURING THE DEMAND FOR ENVIRONMENTAL QUALITY 213-320 (John B. Braden \& Charles D. Kolstad eds., 1991).

${ }^{72}$ See, e.g., Peter A. Diamond \& Jerry A. Hausman, Contingent Valuation Measurement of Nonuse Values, in NATURAL ResourCe Damages 61 (Richard B. Stewart ed., 1995) (critiquing the contingent-valuation methodology).

${ }^{73}$ Although not yet upheld against explicit legal challenge, contingent valuation has been used in a number of CERCLA natural-resource damage assessments, and poses a number of legal issues. See John Daniel Ballbach, A Survey of Natural Resource Damages Cases, in NATURAL ReSOURCE DAMAGES, supra note 72, at 85, 109-10; Richard 
contingent valuation, people are surveyed and asked questions designed to elicit how much they would be willing to pay for environmental cleanup or restoration. ${ }^{74}$ Various criticisms have been made of this practice, ${ }^{75}$ but the only one upon which I wish to dwell here is the charge, leveled by psychologists such as Daniel Kahneman, that contingent-valuation responses reflect not the economic value of collectively held environmental goods, but "a willingness to acquire a sense of moral satisfaction ... by a voluntary contribution to the provision of a public good." The primary evidence for this "moral goods" view is the alleged insensitivity of the stated "willingness to pay" to the scope of the environmental good. More precisely, it is argued that: (1) when subjects are asked for their willingness to pay for a list of environmental goods, their stated willingness to pay for a particular good varies with its position in the list; and (2) willingness to pay for an environmental good is higher when it is considered on its own than when considered as part of a more inclusive good (the "embedding" effect)." The argument was made originally by Kahneman, ${ }^{78}$ who presented a graph illustrating that a survey of Ontario residents showed that these residents were willing to pay almost as much to preserve fish stocks in a single lake as they were to pay to preserve fish populations in all Ontario lakes. ${ }^{79}$ Kahneman argued that if the amount people are willing to pay to preserve collective environmental goods does not vary with the level of those goods, then it must be that their stated willingness to pay does not express an economic valuation of such goods, but rather is a statement as to how

B. Stewart et al., Evaluating the Present Natural Resource Damages Regime: The Lawyer's Perspective, in NATURAI RESOURCE DAMAGES, supra note 72, at 153, 171-73.

${ }^{74}$ See Robert C. Mitchell \& Richard T. Carson, Using Surveys to Value PUblic GoOdS: THE CONTINGENT VALUATION METHOD 2 (1989) (stating that this method "uses survey questions to elicit people's preferences for public goods by finding out what they would be willing to pay for specified improvements in them").

${ }^{75}$ For a collection of criticisms, see CONTINGENT VALUATION (Jerry A. Hausman ed., 1993). See also Daniel Kahneman \& Ilana Ritov, Determinants of Stated Willingness to Pay for Public Goods: A Study in the Headline Method, 9 J. RISK \& UNCERTAINTY 5, 5-7 (1994) (discussing some of the criticisms of the contingent-valuation method).

${ }^{76}$ Daniel Kahneman \& Jack L. Knetsch, Valuing Public Goods: The Purchase of Moral Satisfaction, 22 J. ENVTL. ECON. \& MGMT. 57, 64 (1992).

7 See id. at 58.

${ }^{78}$ See R.G. Cummings et Al., VAluing ENVIRONMENTAL Goods 185-94 (1986) (comments by Professor Daniel Kahneman).

${ }^{79}$ See id. at 191 fig.12.2. 
much they would pay for the "moral satisfaction" of contributing to such goods. ${ }^{80}$

Economists who conduct contingent-valuation surveys have countered the psychologists" "moral goods" approach in a variety of ways. First, they have argued that the econometric evidence does not establish that contingent-valuation surveys indeed are subject to insensitivity to scope. ${ }^{81}$ Theoretically, they have explained that precisely because the kinds of environmental goods subject to contingent valuation are collective, quantity-constrained goods, standard neoclassical economic theory predicts embedding and sensitivity to the order in which a good is presented in a list of environmental goods. ${ }^{82}$ Forbidding money-price allocation means that many people will feel constrained: They would exchange money for greater access to, or more of, the resource, if they were allowed to do so. If, however, one specifies that a larger or more inclusive relationship is already available, then a person may get the relationship she desires as a side benefit, as it were, without paying anything. For instance, if one specifies that a park containing many beautiful lakes has been provided, and then asks how much a lover of lakes would pay to preserve the lakes, then it may well be that the respondent sees little need to pay much of anything, for she believes that provision of the park entails the (nonprice) provision of the lakes. Such an effect might well be found even were one not to say explicitly that the lakes were within the park, given the tendency of people to make implicit assumptions about such relationships.

The simultaneous provision of other collective resources generally will affect how a person values any particular collective resource. Moreover, because collective environmental goods are quantityconstrained, there is no reason to expect a neatly continuous pattern of valuation responses. ${ }^{83}$ Such goods are provided only in discrete increments, rather than in the continuous variations necessary to

${ }^{80}$ See Kahneman \& Knetsch, supra note 76, at 64-67.

${ }^{81}$ For a spirited presentation of this view, see RICHARD T. CARSON, CONTINGENT VALUATION SURVEYS AND TESTS OF INSENSITIVITY TO SCOPE 18-28 (University of Cal., San Diego, Dep't of Econ. Discussion Paper No. 95-05, 1995).

${ }^{82}$ See RICHARD CARSON ET AL., ON THE CREATION AND DESTRUCMON OF PUbliC GoOdS: THE MATTER OF SEQUENCING (University of Cal., San Diego, Dep't of Econ. Discussion Paper No. 95-21, 1995).

${ }_{85}$ The effect of rationing is to create a nondifferentiability or kink in the resource constraint facing a user, so that a discrete increase in the level of the collective resource may produce greatly disproportionate changes in the constrained user's relative valuation. 
smooth valuation. ${ }^{84}$ As a consequence, the amount a person would be willing to pay to protect what she views as a unique resource might not be affected by the availability of other collective resources. Other persons may perceive many substitutes for a particular resource relationship; yet that perception does not imply that such individuals do not value the continued existence of the resource or care about its protection.

In my view, both the contingent-valuation economists and their critics have failed to focus on some of the crucial issues raised by contingent valuation. The first of these is to delimit the class of resources and actions with respect to which current practice makes pricing a meaningful, conceptually coherent possibility. To ask people how much they would pay to enhance a collective good or to prevent its harm is not sensible when we neither require nor allow such payments. Collective resources are regulated not via price, but via controlling their uses and sanctioning impermissible use. It is, therefore, essential that one specify whether the harm or enhancement comes from allowing a new use or prohibiting an existing use, or as a result of varying the level of a current use. My approach predicts that people will feel very differently about variations in the type of use versus variations in the level of care: If one tells people that the Exxon Valdez was the wrong kind of tanker, people will respond very differently than if one tells them that it was piloted with insufficient care. Such a pattern of responses has nothing to do with whether the good is a "moral" or an "economic" good. What is being assessed in such an experimental survey is not a price, but a sanction. The magnitude of sanctions is determined not by the harm caused or averted, but by the conduct at issue. Sanctions are not prices, and there is no reason to expect that the way people assess sanctions will match the way the economic theory of individual behavior predicts they will attach prices. By fashioning surveys that test this proposition, we may go a long way toward resolving the contingent-valuation controversy, as well as toward resolving larger issues regarding the debate between rational economic versus behavioral models of individual behavior. ${ }^{85}$

84 See Arrow, supra note 5, at 759; Epstein, supra note 8, at 690-93.

${ }^{85}$ A promising step in this direction has been taken recently in CASS R. SUNSTEIN ET AL., ASSEsSing PUNITIVE DAMAges (WITH NOTES ON COGNITION AND VALUATION IN LAW) (University of Chicago Law \& Econ. Working Paper No. 50 (2d ser.), 1997). 


\section{B. Protecting Ecosystems}

One of the major environmental policy initiatives of the Clinton administration has been to use Habitat Conservation Plans to fashion an incremental, or noncatastrophic, approach to ecosystem protection. $^{86}$ The goal of the incremental approach is to avoid costly conflicts, triggered when proposed private land-development activities threaten to impair significantly habitats critical to the survival of endangered species. Under the Endangered Species Act (ESA), such activities are subject to an inflexible prohibition, violation of which is subject to civil and even criminal sanction. ${ }^{87}$ The application of such a prohibition inevitably entails the loss of any economic benefits may be generated by the prohibited activity, thus putting regulators in the extremely uncomfortable position of mediating between those who care passionately about threatened species and those who care passionately about private property rights.

The ESA epitomizes what might be termed the catastrophic approach to regulating private relationships with collective resources: One may inflict some harm on the resource without making any money payment or running afoul of any collective rule regarding use, and yet an action that threatens the very existence of the collective resource is prohibited absolutely. Such a regulatory regime refuses to attach a price to the resource. If money penalties are imposed, they are imposed as a sanction for violating a collective prohibition.

${ }^{85}$ The Endangered Species Act (ESA) regulates both private actions that may jeopardize the continued survival of endangered species and (somewhat more broadly) public actions. See 16 U.S.C. $\$ \S 1531-1543$ (1994). The decision whether to list a species is viewed as having enormous consequences. See generally Oliver A. Houck, The Endangered Species Act and Its Implementation by the U.S. Departments of Interior and Commerce, 64 U. CoLO. L. REv. 277, 280-96 (1993) (discussing the listings and exceptions). Congress responded to the catastrophic consequences of listing determination by amending the ESA in 1982 to permit the Interior Department's Fish and Wildlife Service to fashion Habitat Conservation Plans ("HCPs") to allow the taking of an endangered species if the taking is (a) incidental to an activity that would (aside from the ESA) be lawful, and (b) pursuant to an HCP that minimizes the harm caused by such a taking. See 16 U.S.C. $\$ 1539($ a). However, as described by Barton Thompson, few HCPs actually were adopted until 1994. See Barton H. Thompson, Jr., The Endangered Species Act: A Case Study in Takings and Incentives, 49 STAN. L. REV. 305, 315-21 (1997). Indeed, only three long-term regional HCPs were adopted between 1982 and 1994; but from 1995 to June 1996, three more regional HCPs were adopted. See id. at 318. For an account of the tortuous path to one such plan for the Balcones Canyonlands near Austin, Texas, see CHARLES C. MANN \& MARK L. PLUMMER, NOAH'S CHOICE 176-211 (1995).

${ }^{87}$ Inflexible, that is, in the absence of a negotiated HCP. See 16 U.S.C. $\$ \S 1538$, 1540 . 
Catastrophic environmental regulation has been attacked as irrationally precipitating conflicts that result in political compromises that fail to protect species adequately, the prospect of which actually encourages a race to develop potentially critical habitats before they become critical. ${ }^{88}$ On the other hand, incremental approaches, which attempt to anticipate and avoid such conflicts, allow limited development and thus may be seen as an exchange of habitat integrity and species health for economic, job-related benefits, violating the letter and spirit of the ESA.

Empirical evaluation of this point would require a comparison of the activities actually permitted under settlements reached in the shadow of the ESA's absolute prohibition with those allowed under incremental agreements. My purpose here, however, is to apply my theory of prices versus sanctions in the regulation of collective goods to reconceptualize the normative issues raised by catastrophic environmental regulations such as the ESA and wetlands-protection programs. $^{89}$

To apply this approach, we first must reconceptualize the collective resource or good that is protected under the ESA's catastrophic approach. The conventional understanding is that this law protects species, rather than their individual members. ${ }^{90}$ The language and legislative history of the ESA support this understanding, and such an understanding is not inconsistent with congressional amendments to the Act. $^{9 l}$ Nonetheless, the ESA's legislative history makes it equally

${ }^{8}$ See Richard A. Epstein, Babbitt v. Sweet Home Chapters of Oregon: The Law and Economics of Habitat Preservation, 5 SUP. CT. ECON. REV. 1, 33 (1997) ("If there is any sense that private land will be subject to controls, then the best strategy for the private owner is to destroy the habitat before it becomes protected ....").

${ }^{89}$ Under section 404 of the Clean Water Act, the Army Corps of Engineers regulates the development of wetlands under a permit program, subject to (rarely exercised) EPA veto authority. See 33 U.S.C. $\$ 1343$ (a)-(c). Even though the permit process generally is considerably more flexible than the ESA's prohibition on taking endangered species, it too has come under severe attack from developers and property-rights advocates. See Oliver A. Houck, Hard Choices: The Analysis of Alternatives Under Section 404 of the Clean Water Act and Similar Environmental Laws, 60 U. CoLO. L. REV. 773 (1989) (discussing problems with section 404).

${ }^{90}$ Indeed, the ESA has come to be evaluated almost exclusively in scientific terms, that is, in terms of whether its legal structure corresponds to scientific opinions on how to preserve and protect species effectively. See, e.g., ENDANGERED SPECIES RECOVERY (Tim W. Clark et al. eds., 1994); Ronald Carroll et al., Strengthening the Use of Science in Achieving the Goals of the Endangered Species Act: An Assessment by the Ecological Society of America, 6 ECOLOGICAL APPLICATIONS I (1996).

${ }^{91}$ An interesting account of the ESA's legislative history is provided in MANN \& PLUMMER, supra note 86, at 149 ("The [ESA] sprang less from informed policymaking 
clear that Congress was protecting the opportunity for individual persons to come into relationship with the great, flagship species found on our continent, such as the bald eagle. ${ }^{92}$ Indirectly, this is to protect and value the opportunity for individual persons to come into relationship with the wilderness those species inhabit and to ensure that those places are not destroyed. This collective opportunity is not allocated via money prices, and, although the ESA makes possible the acquisition of private lands to enhance and magnify such collective opportunity, such acquisition has been rare. ${ }^{93}$

However difficult in practice, it would be conceptually possible to charge a money price for actions causing harm even to individual members or local species populations. Moreover, whether a species is threatened may have little to do with whether the ability of individual persons to interact with particular species populations is impaired. If, for instance, there are Northern Spotted Owl populations in both California and the Pacific Northwest, then the fact that healthy populations remain in California will not mean there is any less harm suffered by those that live in the Pacific Northwest and rarely visit California. From this perspective, what is remarkable about the ESA is not that it prohibits actions causing the extinction of an entire species, but that it fails to attach any money price to actions harming populations within species.

Under my theory, this must be justified in some way by the effect of failing to charge a money price for harm to populations of species. Here, the accountability aspect of the theory is crucial. If we allowed harm to individual populations to be priced, then we would create an incentive for the agent of the collectivity to promote harm to populations, precisely when those who would be harmed were local groups that were not able to organize and be represented. It would be extremely difficult to determine whether the local harm was offset by collective money benefits. Insofar as local costs were large, there would be an enhanced incentive for the agent to ensure that the money was spent on a concentrated benefit and to alert the beneficiaries of the quid pro quo nature of the benefit they received.

than from the simple aspiration to save everything-to banish extinction from the face of the planet, or at least from the United States.").

${ }_{92}$ See id. at 148 (noting, inter alia, that the ESA may have been designed to protect "bald eagles and grizzly bears").

${ }_{93}$ See Thompson, supra note 86 , at 346 (noting barriers to the government purchase of property, including the requirement of "completing reams of studies and reports" before "mak[ing] a move under the ESA"). 
When, by contrast, we do not allow the agent of the collectivity to charge money prices, we essentially put those persons who value local populations of species at risk that the populations will be destroyed by the actions of their neighbors. Even with the restriction on money exchange, there will be strong incentives for such persons to find a collective way to offer some medium to exchange for restrictions on the development and preservation of local populations. In other words, it is the very fact that the collectivity fails to price individual populations at the level of the species that creates an incentive for local action to protect such populations. By refusing to attach a money price to harm at the population level, catastrophic regulation both refuses to condone such harm and creates local responsibility for avoiding it. With strong human relationships to local populations, the species-extinction problem ought never arise, the catastrophe ought never come to pass.

That it does, and with such seeming frequency, is, in my view, a consequence primarily of the overuse of money exchange for collective resources. When (as has been historically true of the United States Forest Service ${ }^{94}$ ) the agent of the collective derives its revenue substantially, if not entirely, from selling access to and use of the collective resource, the agent's incentives to permit uses that are not in the collective interest are extremely strong. More generally, it does not matter for this purpose whether the money revenue is collected in the form of a direct tax on the quantity of collective good used or on the money revenue generated by the activity that puts the resource to use (as is true of local property taxes); in either event, the agent of the collective will have an interest in allowing uses of the collective resource that are not in the collective interest, but rather that generate private benefits to both the agent and the resource user. On this view, species become extinct not because governments do not charge money prices for harm to species, but instead because they do.

\section{Assessing Regulatory Alternatives}

The existing economic approach to assessing alternative regulatory regimes for protecting the environment may be summarized,

For a comprehensive discussion of the evolution of the legal framework governing the Forest Service's management of the national forests, see Charles F. Wilkinson \& H. Michael Anderson, Land and Resource Planning in the National Forests, 64 OR. L. REV. 1 (1985). 
without oversimplification, by the refrain, "More markets!" The conventional economic argument is that we have now reached the stage at which collective environmental resources are subject to such intense use that the administrative and transaction costs of administering a regime of explicit money prices for access to and relations with these resources are more than justified in light of the cost (and incentives) of alternative command and control regulatory regimes. ${ }^{96}$ Much of this argument's force is derived from the fact that the costs of the existing command and control regime are large and obvious, and from the quite sound intuition that collective environmental goods will be overused if users are not somehow made to internalize the harm to others caused by their use.

The argument developed above shows why the actual implementation of a pricing regime may be much more complex than commonly is supposed. There are two kinds of prices: (1) taxes or effluent fees, prices that would be imposed by the agent of the collective (for example, the EPA) on the basis of the harm caused; and (2) tradable permits or quotas, which would be allocated by the agent of the collective in predetermined quantities, and then traded freely for money by those possessing such rights. My earlier analysis applies quite directly to show the insuperable difficulty of implementing a taxation scheme that charges appropriate prices and creates sound regulatory incentives. Especially at the level of federal environmental regulation, the informational demands to set appropriate taxes are enormous. Even if private valuations can be estimated in acceptable ways, ${ }^{97}$ the agency costs introduced by exchanging money for environmental harm are likely to swamp any desirable effect on private incentives in using collective goods.

${ }^{95}$ See, e.g., Daniel J. Dudek \& John Palmisano, Emissions Trading: Why Is This Thoroughbred Hobbled?, 13 COLUM. J. ENVIL. L. 217, 219 (1988) ("Successful resolution of increasingly complex local and global air quality problems requires greater emphasis on decentralized trading programs and less on omniscient bureaucracy."). For a more general argument in favor of market incentives in environmental protection, see Bruce A. Ackerman \& Richard B. Stewart, Reforming Environmental Law: The Democratic Case for Market Incentives, 13 COLUM. J. ENVTL. L. 171, 173-88 (1988).

${ }^{96}$ See Ackerman \& Stewart, supra note 95, at 172-88 (describing the current deficiencies in the command and control regulatory strategy and recommending instead marketable permits).

${ }_{97}$ This may be done, for instance, by gathering market data on the premia demanded by persons in exchange for exposure to certain health risks. But see PETER DORMAN, MARKETS AND MORTALITY 51-106 (1996) (describing and critiquing various ways of inferring willingness to accept varying degrees of risk of death from market behavior, such as wage premia for risky occupations). 
As for tradable quotas or permits, observe first that the performance of such a scheme depends upon the first-stage decision regarding the permissible overall level of the activity. Now this is, of course, dependent upon some means of assessing individual and collective values. The valuation problem is not avoided but confronted head on in choosing aggregate levels of harm or emissions. It may be (and often is) ${ }^{98}$ asserted that the argument for tradable quotas is purely second-best: Given any particular aggregate-level target, the cheapest way of achieving that level is through tradable quotas. My theory suggests, however, a fundamental limitation on the applicability of such a rationale. The value of sanctions is in allowing the agent of the collective to stop harmful uses as soon as the harm is perceived and early enough for the sanctions to be effective in labeling the violator. If a user not only has a quota, but also has a quota that by right she may increase via money exchange, then the decision already has been made not only that the type of use is permissible, but also that any level of emissions caused thereby is permissible as well, as long as the user pays for the increase. This suggests that tradable emission quotas are appropriate only for those emissions that are customary and known to be on balance in the collective interest, regardless of the level of emissions. As a consequence, the case for tradable sulfur dioxide permits under the Clean Air Act's acid-rain program $^{99}$ may depend very strongly on the fact that the entities covered by the program are regulated public utilities, the actions of which traditionally have been certified by an agent of the collective as being in the local public interest. ${ }^{100}$ The deregulation of the electricutility industry is therefore of direct relevance on this account to the case for tradable permits: Without regulatory oversight of the activity, both the way and level at which it is conducted must be newly evaluated.

\section{CONCLUSION}

Composed as an alternative to grand theories of incommensurable goods and values, my argument has posited an underlying socio-

${ }^{98}$ See, e.g., T.H. TIETENBERG, EMISSIONS TRADING (1985).

${ }^{99}$ See 42 U.S.C. $\$ \S 7651-7651$ o (1994).

${ }^{100}$ The incentives for rate-of-return regulated electric utilities created by the tradable emission-allowance program under Title IV of the 1990 Clean Air Act Amendments are analyzed in Don Fullerton et al., Sulfur Dioxide Compliance of a Regulated Utility, 34 J. ENVTL. ECON. \& MGMT. 32 (1997). 
economic, functional explanation for the widespread condemnation of certain kinds of explicit money exchange. Trust is of enormous value to a market economy, but trust cannot be learned unless there are some relationships that are insulated from exchange in the common medium. Just as we all gain by having among us those who know how to cooperate, to keep their word, and to lend a helping hand, so too do we all gain by having among us those who care for and understand the natural environment, and will perform the promise of stewardship implicit in private ownership. Pricing a service is indeed a way to see that it is not undervalued. But attaching money prices to some services defeats their social and economic purpose. Instead, we regulate uses and relationships, sanctioning those that fall far from the range of the permissible, both to facilitate nonlegal means of control and regulation, and to ensure that the incentive to monitor the collective welfare does not become an invitation for rent-seeking by private actors and public agents.

These themes necessarily have been developed incompletely here. Still, I hope to have shown at least that the explanation for "incommensurability" rests not on highly abstract theories of individual choice or aggregate welfare, but on the concrete benefits of social and environmental cooperation. 
$*$

$*$

$*$ 